\title{
Maatalousyrittäjyyden koulutus erikoistuu ja moninaistuu
}

\author{
Lassi Puupponen
}

\begin{abstract}
Nykypäivän ja vielä enemmän tulevaisuuden maatalousyrittäjä on vallan muuta kuin menneiden vuosikymmenten omavaraistalouteen tai pienimuotoiseen moninaisuuteen elinkeinonsa perustanut maanviljelijä. Alan koulutus on tässä muutoksessa edelläkävijä.
\end{abstract}

$\mathrm{M}$ aatalousalan koulutuksen alkamisesta tuli viime vuonna kuluneeksi 160 vuotta: marraskuun alussa 1840 tulivat ensimmäiset opiskelijat Mustialaan. Heitä tuli maanviljelyskouluun, pellavanvalmistusopistoon ja lammashoitokouluun. Tästä lähtien on maatalouteen ja maaseudulle koulutettu sekä yleis- että erikoisosaajia. Maataloudessa on aina ollut tarvetta myös erikoisosaajille. On tarvittu karjakoita, tilanhoitajia ja pehtooreita. Maatalousalan koulutukseen on aina kuulunut myös yrittäjyyskoulutusta, sillä monet ovat koulun jälkeen siirtyneet oman tilan pitäjäksi, maatalousyrittäjiksi. Maatalousyrittäjän pitää hallita myös tilansa talous, ei pelkästään biologinen tuotanto.

Maatalouden ja maatalouskoulutuksen perusta on yhä sama kuin 160 vuotta sitten. Maanviljelijä, maatalousyrittäjä, toimii samojen biologisten reunaehtojen säätelemänä kuin ennenkin. Yhteiskunnallinen toimintaympäristö on kuitenkin erilainen. Viimeistään siirtyminen EU-Suomeen muutti maatalousyrittäjyyden toimintaympäristöä. 1970-luvulla alkanut erikoistuminen on jatkunut. Se voi tapahtua maataloustuotannon sisällä erikoistumalla viljanviljelyyn, maidontuotantoon, naudan- tai sianlihantuotantoon, porsastuotantoon tms. tai voidaan erikoistua johonkin maatalouden liitännäistuotantoon, esimerkiksi metsätalouteen. Erikoistua voidaan myös täysin maatalouden ulkopuoliseen tuotantoon, näistä yrittäjistä on esimerkkeinä Pohjanmaan puusepät ja mattokutomot.

Koulutuksen on kehityttävä ajassa. KoulutukKsen pitää vastata sekä yhteiskunnan, työelämän että koulutettavien vaatimuksiin ja toivomuksiin. Maatalousalan koulujen opintotarjontaan on tullut uusia opintojaksoja, osaltaan opiskelijoiden toivomuksesta, osaltaan oppilaitoksen oman tuotekehittelyn ja toiminnan tuloksena. Mustialassa tarjoamme perinteisen maatalouden ja maaseutuyrittämisen lisäksi opintoja mm. oluen valmistamisessa, erätaidoissa, maaseutumatkailussa sekä suomeksi että englanniksi, hirsirakentamisessa ja Euroopan ruokataloudessa. Joissakin alan oppilaitoksissa saa opetusta tilaviinin tuottamisesta, tilateurastuksesta, eräopastuksesta tai luontomatkailuyrittäjyydestä, puhumattakaan luomutuotannosta sekä hevos- tai puutarhataloudesta. Tarkoituksena ei kuitenkaan saa olla se, että tarjotaan opintoja vain huvin ja erikoisuuden vuoksi, vaan opintojen on tarjottava opiskelijan tietoihin ja taitoihin jotain sellaista lisää, jolla hän voi parantaa omaa asemaansa työelämässä tai saada lisäoppia omiin tarpeisiinsa.

Maaseudun ihmisten kouluttajan näkökulmasta tilanne saattaa tulevaisuudessa olla se, että uusista opiskelijoista vain pieni osa tekee elämäntyönsä perinteisessä maataloustuotannossa. Nämä 
opiskelijat tarvitsevat kuitenkin todella syvälle menevän koulutuksen sekä omaan tuotannonalaansa että yrittäjyyteen ja talouteen. Heidän tilansa ovat suurempia, heillä on enemmän eläimiä hoidettavanaan ja heillä on oltava yhä enemmän tietoa sekä tuotannosta että taloudesta. Tämä on maatalousyrittäjän erikoistumista. Osa opiskelijoista sijoittuu maatalouden kauppaa, neuvontaa tai hallinnointia harjoittaviin organisaatioihin. Osa etsiytyy maaseutua muuten hyödyntäviin ja sille palveluja tarjoaviin työpaikkoihin. Uutena alana on esimerkiksi maatilatalouden perustutkintoon tulossa ympäristöpalvelujen tuottaminen -opintokokonaisuus (20 ov), jonka sisältönä on maatiloille ja muille maaseudun asukkaille tarjottavat ympäristöpalvelut.

$\mathrm{V}$ äistämätön kehitys on se, että maatilat Suomessa vähenevät, 90-luvulla 50000 tilaa on lopettanut. Eri asia on se, tarvitseeko maaseudun yritysten samalla vähetä vai löytääkö, etsiikö, tarvitseeko luopuva maatalousyrittäjä uuden alun elämälleen maaseutuyrittäjänä. Maaseutuyrittäjän juuret eivät tarvitse olla maalla, mutta hänen on suhtauduttava myönteisesti elämään maaseudulla. Opetuksessa on lähdettävä siitä, että kaikista ei voi, eikä pidä tulla yrittäjiä, mutta yrittämisen asennetta tarvitaan kaikkialla. Maatalousopetukseen ei tarvitse tehdä isoa remonttia, sillä yrittäjämäinen maatalous on ollut aina mukana opetuksessa. Koulutuksessa, muissakin kuin vain yrittäjyyttä käsittelevissä opinnoissa, pitää näkyä myönteinen suhde yrittäjämäiseen toimintaan myös toteutuksessa, eikä vain opetussuunnitelmissa. Erikoistuvalle maaseutuyrittäjälle koulutuksen tulee antaa valmiudet kaikenlaiseen yrittäjyyteen. Tätä voi oppilaitos käyttää myös vetovoimatekijänä: Entäpä, jos tulisit meille opiskelemaan voit sisällyttää opintoihisi runsaasti kaupallisia ja yrittäjyysaineita, annamme sinulle myös vähän maatalousopetusta. Mustialasta valmistuneita toimii perinteisen maatilatalouden lisäksi musiikkikauppayrittäjinä, vuohijuustoyrittäjinä, maansiirtokonekauppiaina, neuvonta-alan yrittäjinä ym.

$\mathrm{J}^{\mathrm{s}}$ otta opetukseen saadaan yrittäjälähtöisyyttä, voidaan maaseudun yrittäjiä käyttää luennoijina ja innostajina, opinnäyte- ja päättötöitä voi- daan ohjata yrittäjämäiseen otteeseen ja harjoittelupaikoissa voidaan suosia sellaisia, joissa ote on yrittäjämäinen. Uusi mahdollisuus, jota on joissakin oppilaitoksissa jo toteutettu, on oppilaitoksessa tai yhteistyössä jonkin organisaation kanssa toimiva yrityshautomo, joka on tarkoitettu joko omille opiskelijoille tai myös ulkopuolisille aloitteleville yrittäjille. Oppilaitoksen oma yritystoiminta esimerkkinä opiskelijoille on jonkin verran kiistelty aihe. Pitääkö/saako oppilaitos laajentaa reviiriään alueelle, jolla toimii myös yksityisiä vai onko oppilaitoksen tehtävä tehdä vain koulutus-, kehitys- ja tutkimustyötä? Maatalousalan oppilaitoksilla on oma maatila, puutarhaoppilaitoksilla kasvihuoneet ja ravintola-alan oppilaitoksilla opetusravintola ja näissä tuotteet ja palvelut myydään markkinahintaan. Entäpä maatalousalan oppilaitoksessa ravintola, jossa myydään koulun oman panimon tuotteita? Olemme joutuneet pohtimaan tätä asiaa, ja olen sitä mieltä, että jos emme polje hintoja, haemme oman, paikallisista eroavan, profiilimme ja täytämme raon, joka markkinoilla on, voimme harjoittaa yritystoimintaa.

\section{Luonnonvara- ja luonto- yrittäjyys kasvussa}

$\mathrm{L}$ uonnonvara-alan oppilaitoksissa lähtökohtana on maaseudun hyödyntäminen. Maaseutu- ja luontomatkailu ovat maaseutuun, jossain määrin myös maatalouteen, liittyvää erikoistumista, nekin hyödyntävät maaseutua ja luontoa. Suomessa on joitakin luonnonvara-alan oppilaitoksia, joissa on mahdollista saada koulutusta matkailussa. Nämä uudet alat tuovat oppilaitokseen uutta osaamista sekä alasta että alan taloudesta ja 
yrittäjyydestä. Usein matkailun opetuksesta vastaavat ihmiset, joilla ei ole maataloudellista näkökulmaa. Tämä rikastuttaa oppilaitosta, maatalousalan ihmisten näkökulma maaseutuun laajenee ja oppilaitos saa uutta puhtia.

Hämeen ammattikorkeakoulussa Forssassa toimii matkailun koulutusohjelma, jonka sivuainevaihtoehdoissa on mahdollista opiskella luontomatkailua, maaseutumatkailua ja liikematkailua. Koulutus on järjestetty niin, että luontomatkailun osiosta vastaa metsätalouden koulutusohjelma Evolla ja maaseutumatkailusta maaseutuelinkeinojen koulutusohjelmassa Mustialassa. Suurin osa opiskelijoista on lähtöisin muualta kuin maaseudulta, mutta opiskelu maaseutualan oppilaitoksessa varmaan vähentää maa- ja kaupunkiseudun ristiriitoja. Näihin matkailualan opintoihin osallistuu vuosittain muutama meidänkin opiskelijamme. Enemmänkin omia opiskelijoita voisi matkailua opiskella, sillä maaseudulle matkailu antaa tulevaisuudessa lisäansioita.

Omassa toiminnassaan myös Mustiala on panostanut maaseutumatkailuun. Viimeisen 5-6 vuoden aikana olemme rakentaneet panimon ja oluttuvan, aloittaneet ruokala- ja majoitustoiminnan myynnin myös ulkopuolisille. Matkailumme työllistää kolmisen henkeä ympäri vuoden. Kesäaikaan matkailumme tarjoaa harjoittelupaikan 2 4 opiskelijalle. Matkailu ja sen koulutus ovat tuoneet meille myös ulkomaisia opiskelijoita. Englanniksi luennoitaviin matkailun opintojaksoihin osallistuu vuosittain kymmenkunta opiskelijaa mm. Baltian maista, Ranskasta, Saksasta ja Espanjasta. Mustialan matkailussa oli vuonna 2000 kaksi harjoittelijaa Kreikasta ja vuonna 2001 saamme kaksi harjoittelijaa Portugalista. Tämäntyyppinen, oppilaitoksessa luontevasti tapahtuva kansainvälisyys, on tulevalle maaseutuyrittäjälle erityisen arvokasta.

Mustialan oman yritystoiminnan laajeneminen perinteisen maataloustuotannon ulkopuolelle alkoi syksyllä 1994, kun aloitimme pienpanimoyrittäjän koulutuksen. Koulutusta aloitettaessa meillä ei juurikaan ollut tietoja tai taitoja alasta, muuten kuin oluen käyttäjinä. Jälkeenpäin ajatellen ei koskaan pitäisi aloittaa koulutusta niin vähillä tiedoilla, mutta onneksi muutaman onnekkaan sattuman avulla, saimme rakennettua koulutuksen, jonka kävi läpi 120 opiskelijaa seitsämällä eri kurssilla viiden eri vuoden aikana. Alusta pitäen oli selvää, että koulutuksessa oli oluen valmistamisen lisäksi myös pienpanimon taloutta käsittelevä osio. Tätä vaati myös oluen valmistamista valvova viranomainen, jonka haastatteluun jokainen pienpanimon perustamista suunnitteleva joutuu lupaa hakiessaan.

\section{Taito uusia omia tietoja ja taitoja}

$\mathrm{V}$ altava tiedon määrä, joka koko ajan lisääntyy, asettaa koulutuksella uusia vaateita. Emme voi lähteä siitä, että opiskelija saa oppilaitoksesta kaiken sen tiedon, mitä hän seuraavien vuosien aikana tarvitsee. Meidän on saatava opiskelija ymmärtämään uuden tiedon etsimisen ja hankkimisen tärkeys, jos haluaa pysyä ajantasalla. Ilokseni olen huomannut, opinnäytetöitä ohjatessani, että olemme taitaneet onnistua, sillä opiskelijoilla on hyvät tiedot siitä, mitä maailmalta voi löytää ja kuinka sen sieltä onnistuu löytämään. Oppilaitoksen merkitys ei enää olekaan opettaminen, vaan sen pitää antaa opiskelijalle mahdollisuus oppia. Opettaja on enemmän ohjaaja kuin tiedon jakaja.

Tulevaisuuden maaseutuyrittäjä tarvitsee pitkälti samoja oppeja kuin aikaisempien vuosikymmenien esi-isänsä. Maataloudessa toimivalla pitää olla vankat tiedot ja taidot niistä biologisista perusteista, joihin maataloustuotteiden tuottaminen perustuu. Biologisten perusteiden lisäksi maatalousyrittäjä tarvitsee tietoja ja taitoja niistä talouden lainalaisuuksista, jotka säätelevät maatalouden yritystoimintaa. Maatalousalan oppilaitosten pitää toimia ajassa ja laajentaa opetustarjontaansa tai rakentaa yhteistyökuvioita toisiin oppilaitoksiin niin, että opiskelijoille voidaan tarjota tai että opiskelija voi sisällyttää opintoihinsa aineita, joista on opiskelijalle hyötyä tulevassa toiminnassa maaseudulla yrittäjänä, neuvojana tai maaseudun asujana ja toimijana. Kaikille opiskelijoille pitäisi opettaa yrittäjämäistä asennetta, jota tarvitsevat muutkin kuin yrittäjinä toimivat. 